Ж. Ж. Варбот (Москва, Россия)

\title{
К семантике и генетическим связям праслав. *tem-/ *tom- (на материале восточнославянской диалектной лексики) ${ }^{1}$
}

Продвижение исследований по реконструкции праславянского лексического фонда, особенно в словарной форме, предполагающей последовательный охват всей потенциальной праславянской лексики (см. ЭССЯ), убеждает в необходимости возможно более полного привлечения лексики славянских диалектов, часто восполняющей лакуны в материалах литературных языков в отношении представления этимологических гнезд, их структурных и семантических характеристик и индоевропейского родства.

Реконструкция праслав. глагола *tęti/*tbmo 'давить, сбивать, сжимать', основанная на генетическом отождествлении корней глаголов словен. stéti se, stámem se 'сгустеть' и диал. словен. raztêmati se 'растопиться, распуститься', сербохов. utémati, ùtemam 'забить' позволила объяснить славянские родственные связи для праслав. *tomiti (Boryś 1981: 25-29; Boryśs 2007: 242-245). Последний имеет следующие продолжения в славянских языках: ст.-слав. томнтн 'испытывать, пытать', болг. диал. (Банско) то́ле 'соблазнять, возбуждать желание', сербохорв. tòmiti ‘давить', словен. tomljati 'слоняться', русск. толить 'мучить; (о еде) обрабатывать теплом в закрытом сосуде, без доступа воздуха', укр. толити то же, блр. таліиь то же. Этимологические исследования

1 Статья написана при реализации проекта «Лексика славянских языков как наследие и развитие праславянского лексического фонда: словообразовательный, семантический и этимологический аспекты анализа в лексикографическом представлении», поддержанного грантом РФФИ № 19-012-00059. 
привели ранее, до реконструкции праслав. *tęti / tomo, к гипотезе о первичности для *tomiti семантики *'лишать воздуха, удушать' и возведению его к и.-е. *tem- 'оглушенный, расслабленный (лишенный воздуха)’ (Pokorny I: 1063; Skok III: 480; БЕР 8: 110). Лексические соответствия для *tomiti из и.-е. языков достаточно убедительны.

Реконструировав праслав *tęt/*tьm и и истолковав этот глагол как производящий для *tomiti, Бориш распространил версию о происхождении *tomiti из гнезда и.-е. *tem- также и на исходный праславянский глагол *tęti/*tbmo (Boryśs 2007: 245). Польск. ciemęa 'вялый, нескладный человек', очевидно семантически близкое к и.-е. *tem- 'оглушенный, расслабленный, истолковано как производное от *ciemiać, *ciemić, соответствующих сербохорв. *temati 'давить' (см. выше utémati 'забить') (Boryś 2005: 79-80). Семантика словен. stéti se, stámem se 'сгустеть' толкуется Боришем из *'сдавиться, сбиться', а сербохорв. 'забить' рассматривается как реликт 'сдавить', и далее предполагается семантическое тождество с 'душить' (Borý́ 2007: 27), отсылающее как будто к и.-е. *tem- 'оглушенный, расслабленный (лишенный воздуха)'. Очевидно слияние в семантике словен. stéti se, stámem se 'сгустеть' семантических составляющих 'сдавиться’ и 'сбиться’. Физическая сущность обозначаемых глаголов давить и бить очень близка и может быть источником для семантики 'душить' (ср. чеш. dusit 'давить, душить' и dusat 'сбивать, трамбовать'), однако все-таки семантика 'душить' как исходная для гнезда *tęt/*tbmo может предполагаться только на основе значения 'обрабатывать теплом без доступа воздуха' восточнославянских продолжений * tomiti.

Расширение круга потенциальных лексических продолжений этимологического гнезда праславянского глагола *tęi/*tbmo за счет русских и белорусских диалектизмов, ранее не рассматривавшихся в аспекте родства с *tomiti и приведенной выше южнославянской лексикой, позволяет уточнить исходную семантику гнезда. Диалектизмы 
обнаруживают несколько семантических характеристик. Прежде всего, это отражение глагольной семантики сдавливания = сплочения: русск. арханг. прито́л 'хлев для скота; место в реке, озере, где скапливается рыба' (СРНГ 32: 19); соединение семантики сплочения с семантикой направления движения: русск. прити́л 'о главном, важном месте, направлении и т. п.', дон. жить на прити́ле 'жить на людном месте (где сходится много дорог)', иркут. в прити́л 'плотно' (возможно, сюда же первично и русск. волог. прити́литься 'притихнуть, выжидая') (СРНГ 32: 14-15); семантика преследования: русск. диал. утя́литься мордов. 'пойти, направиться куда-л.', нижегор., влад., яросл., костр. 'пойти за кем.-л. следом, увязаться', урал. 'погнаться за кем-л.' (СРНГ 48: 229); семантика направления взгляда, смотрения: русск. курск., яросл. уте́лить 'устремить, уставить (взгляд)', яросл. уте́лить глаза на кого-л. 'засмотреться на кого-л.', волог. ymúлить 'устремить взгляд в одну точку, неотступно следовать постоянной цели’ (СРНГ 48: 148, 157); семантика сообщения: русск. кольск. вте́лить 'сказать, сообщить' (СРНГ 5: 226), ср. русск. обск. подтоли́mь 'подсказать' (Сл. русск. говоров Оби. Доп. II: 94); семантика внимания и понимания: блр. прыце́ліць 'заметить' (Народ. слова: 96), ия́яміuь 'понимать, схватывать' (Касьпяровіч 1927: 340). Очевидно, семантика сплочения соответствует первичности семантики *tęti*tbmo 'давить, сдавливать'. Семантика направления взгляда, смотрения и сообщения вторична по отношению к семантике следования, преследования, погони, а семантика смотрения объясняет появление семантики понимания. Семантика следования/преследования/погони близка к семантике направленного толчка = удара, следовательно, к семантике южнославянских глаголов 'забить' и 'сбиваться'. Существенно, что почти все восточнославянские диалектизмы представляют первичную огласовку корня *tem-. Поэтому диалектный семантический комплекс может рассматриваться как аргумент в поддержку первичности для 
праслав. *tęti / tbmo семантики 'бить' / ‘сбиваться', при производности от нее семантики 'давить' и появлении только на основе последнего (как третьего этапа) семантики *'душить' (= восточнослав. 'обрабатывать без доступа воздуха'). Это позволяет предположить для праславянского глагола происхождение от и.-е. *stem- 'толкать, ударять' (лит. stùmti 'колотить, толкать', см. Pokorny I: 1021) с производностью от последнего и.-е. *tem- 'оглушенный, расслабленный (лишенный воздуха)', ср. образование и мотивацию русск. ударенныци, чокнутьıй.

\section{Литература}

БЕР - Български етимологичен речник / съст. Вл. Георгиев, Ив. Гълъбов, Й. Заимов, Ст. Илчев, Т. Тодоров и др. София: БАН. Т. 1-, 1971-.

Касьпяровіч 1927 - Касьпяровіч M. I. Віцебскі краёвы слоўнік (матер'ялы). Віцебск: Заря Запада, 1927.

Народ. слова - Народнае слова / пад рэд. А. Н. Баханькова. Мінск: Навука і тәхніка, 1976.

Сл. русск. говоров Оби. Доп. II - Словарь русских старожильческих говоров Средней части бассейна р. Оби / Томский гос. ун-т им. В. В. Куйбышева; под ред. доц. В. В. Палагиной. Т. 2: [Ж - О] / [сост. словар. статей: В. В. Палагина, О. И. Блинова, М. Н. Янценецкая и др.]. Томск: Изд-во Томского университета, 1965.

СРНГ - Словарь русских народных говоров / гл. ред. Ф. П. Филин, Ф. П. Сороколетов, С. А. Мызников. Л. (СПб.); М.: Наука. Вып. 1-51, 1965-2019.

ЭССЯ - Этимологический словарь славянских языков. Праславянский лексический фонд / под ред. О. Н. Трубачева (вып. 1-31), О. Н. Трубачева и А. Ф. Журавлева (вып. 32), А. Ф. Журавлева (вып. 33-39), А. Ф. Журавлева и Ж. Ж. Варбот (вып. 40), Ж. Ж. Варбот (вып. 41). М.: Наука, 1974-2018-. Вып. 1-41-.

Boryś 1981 - Boryś W. Na tropach słowiańskich reliktów leksikalnych // Rocznik slawistyczny. T. 42. 1981. S. 25-29.

Boryś 2005 - Boryś W. Słownik etymologiczny języka polskiego. Kraków: Wydawnictwo Literackie, 2005.

Boryś 2007 - Boryś W. Etymologie słowiańskie i polskie. Warszawa: Slawistyczny Ośrodek Wydawniczy (SOW): Institut slawistyki PAN, 2007. 
Pokorny - Pokorny J. Indogermanisches etymologisches Wörterbuch. Bern: Francke Verlag. Bd. 1-2. 1948-1959.

Skok 1971 - Skok P. Etimologijski rječnik hrvatskoga ili srpskoga jezika

Knj. 1-4. Zagreb: Jugoslavenska Akademija znanosti i umjetnosti, 1971.

\section{On Semantics and Genetic Connections of Proto-slav. *tem- / *tom- (on the Material of East Slavic Dialect Lexic)}

Reconstruction of Proto-slav. lexical fund requires researches of dialect lexic. Verb family *tem- /*tom- was reconstructed with supposed semantics 'strangle' and genetic connection with I.-E. *tem'stuned (= deprived of air)' on the base of South Slavic lexicon. In the article some dialect East Slav. verbs are analysed as additions to Proto-slav. *tem- / *tom- and on the base the initial semantics of the family is reconstructed as 'beat'. So the genetic connection of Protoslav *tem-/*tom with I.-E. *stem- 'beat' ( $*^{*}$ tem- 'stuned (= deprived of air)') is supposed.

\section{DOI:10.31168/0459-6.16}

\section{М. Н. Саенко (Москва, Россия)}

\section{Реконструкция семантики праслав. *kъlkъ}

Ранее нами было показано, что в праславянском между словами *bedra и *stegno существовало семантическое различие: *bedra имело значение 'боковая поверхность таза', в то время как *stegno означало 'часть ноги от коленного сустава до тазобедренного' (Саенко 2020).

Еще одним словом, семантически связанным с бедром и реконструируемым для праславянского уровня, является *kъlkъ. Сперва рассмотрим семантику его потомков в славянских языках.

В первую очередь это болгарское кблк/кб́лка 'бедро', довольно широко представленное в диалектах (ОЛА 9/44; 